\title{
PERANCANGAN SISTEM INTERAKTIF BERBASIS ANDROID UNTUK MEMBANTU PROSES PENCATATAN DALAM PENEGAKAN DIAGNOSIS PENYAKIT INFEKSI VIRUS PADA ANAK DI POLI ANAK RUMAH SAKIT UMUM DAERAH (RSUD) WANGAYA KOTA DENPASAR
}

\author{
I Made Mahardika ${ }^{1)}$ Bambang Hadi Kartiko ${ }^{2)}$ Gerson Feoh $^{3)}$ \\ Program Studi Perekam dan Informasi Kesehatan ${ }^{1) 2}$ \\ Program Studi Teknik Informatika ${ }^{3)}$ \\ Fakultas Ilmu Kesehatan Sains dan Teknologi, Universitas Dhayana Pura ${ }^{1)}$ 2) 3) \\ dikamahardika18@gmail.com ${ }^{1)}$ gerson.feoh@undhirabali.ac.id ${ }^{3)}$
}

\begin{abstract}
The process of recording the diagnosis of viral infection in children in the polyclinic of Wangaya Hospital is still using manual method. The development of information technology increasingly advanced to the health world. With the application of technology in the world of health will be able to facilitate in performing services to patients. However, with the development of technology, a system is needed to facilitate medical staff to provide medical services to patients. To answer those needs, an interactive system was built to help record the diagnosis of viral disease in children. This interactive system is designed based on Android using the programming language PHP and uses a database of MYSQL. The workings of this interactive system is by asking questions such as symptoms or complaints experienced by the patient, then this system will make the process of analysis based on the percentage likelihood of a diagnosis of the patient's illness. This interactive system can help record the diagnosis of viral infection. In addition to showing the results of diagnosis, the system can also display the definition of each viral infectious disease in children, which has been inputted into the database application.
\end{abstract}

Keywords: Interactive System, Android, Diagnosis of Virus Infections on Children

\begin{abstract}
ABSTRAK
Dalam melakukan pencatatan diagnosis infeksis virus pada anak di poliklinik anak di RSUD Wangaya masih menggunakan cara manual. Perkembangan teknologi informasi semakin berkembang hingga ke dunia kesehatan. Dengan adanya teknologi dalam dunia kesehatan akan mempermudah dalam melakukan pelayanan kepada pasien. Dengan perkembangan teknologi maka sangat di perlukan suatu sistem yang akan mempermudah petugas medis dalam memberikan pelayanan medis kepada pasien. Sistem interaktif dibangun bertujuan untuk membantu pencatatan diagnosis penyakit virus pada anak. Sistem interaktif ini di rancang berbasis Android dengan menggunakan bahasa pemrograman PHP dan menggunakan database dari MYSQL. Cara kerja sistem interaktif ini adalah dengan memberikan pertanyaan berupa gejala-gejala atau keluhan yang di alami oleh pasien, lalu sistem ini akan melakukan proses analisis berdasarkan presentase kemungkinan diagnosis dari penyakit pasien tersebut. Sistem interaktif ini akan dapat membantu pencatatan hasil diagnosis penyakit infeksi virus. Selain menampilkan hasil diagnosis sistem ini juga dapat menampilkan definisi dari setiap penyakit infeksi virus pada anak yang telah diinput kedalam database aplikasi.
\end{abstract}

Kata Kunci : Sistem Interaktif, Android, Diagnosis Penyakit Infeksi Virus pada Anak 


\section{PENDAHULUAN}

Sistem pakar adalah suatu program komputer yang dirancang untuk mengambil keputusan seperti keputusan yang diambil oleh seorang atau beberapa orang pakar. Dalam penyusunannya, sistem pakar mengkombinasikan kaidah-kaidah penarikan kesimpulan (inference rules) dengan basis pengetahuan tertentu yang diberikan oleh satu atau lebih pakar dalam bidang tertentu. Kombinasi dari kedua hal tersebut disimpan dalam komputer, yang selanjutnya digunakan dalam proses pengambilan keputusan untuk penyelesaian masalah tertentu. Tujuan utama sistem pakar bukan untuk menggantikan kedudukan seorang ahli atau seorang pakar, tetapi hanya untuk memasyarakatkan pengetahuan dan pengalaman dari para pakar. Seiring pertumbuhan populasi manusia, maka di masa yang akan datang sistem pakar ini diharapkan sangat berguna membantu dalam hal pengambilan keputusan. Selama ini aplikasi sistem pakar hanya terdapat berupa aplikasi web, namun perkembangan teknologi berkembang semakin pesat terutama teknologi mobile Android yang telah memiliki beragam aplikasi untuk segala kebutuhan, teknologi mobile dapat diakses dengan mudah dan cepat karena mudah dibawa kemana-mana, tidak memerlukan ruang yang besar. Teknologi mobile Android akan mempermudah untuk melakukan diagnosa awal.

Dengan metode konvensional (men-deteksi gejala secara manual tentang apa yang dirasakan pasien) akan memakan waktu yang sangat lama dan masalahnya sekarang bukan hanya perlu mengetahui penyebab pen-yakit tetapi yang penting adalah mengetahui dengan cepat penyakit yang diderita serta penanggulangannya, agar penyakit yang diderita oleh anak tidak berdampak dan dapat segera diobati. Sistem yang terintegrasi dalam komputer hari ini memungkinkan menyimpan data dengan jumlah besar, mencari data yang tersimpan dengan waktu yang singkat bahkan, ada juga yang menjadikan komputer sebagai alat pemberi pertimbangan dalam menentukan kebijakan. Seiring berkembangnnya ilmu pengetahuan dan teknologi, informasi sudah semakin mudah diperoleh, semakin bervariasi bentuknya dan semakin banyak pula kegunaanya (Wahyu, 2004).

\section{TINJAUAN PUSTAKA}

\section{Pengertian Perancangan Sistem}

Perancangan sistem adalah proses pengembangan spesifikasi sistem baru berdasarkan hasil rekomendasi analisis sistem. Dalam tahap perancangan, tim kerja desain harus dirancang spesifikasi yang dibutuhkan dalam berbagai kertas kerja. Kertas kerja itu memuat berbagai uraian mengenai input, proses, dan output dari sistem yang diusulkan.

\section{Sistem Informasi}

Sistem adalah sekumpulan elemen yang saling terkait atau terpadu yang dimaksudkan untuk mencapai suatu tujuan. Sistem juga dapat didefinisikan sebagai kumpulan/grup dari bagian atau komponen apapun baik fisik ataupun non fisik yang saling berhubungan satu sama lain dan bekerja sama secara harmonis untuk mencapai suatu tujuan tertentu.

Informasi merupakan salah satu sumber daya penting dalam suatu organisasi digunakan sebagai bahan pengambilan keputusan. Sehubungan dengan hal itu, informasi haruslah berkualitas. Kualitas informasi ditentukan oleh tiga faktor yaitu relevansi, ketepatan waktu dan akurasi.

\section{Pengertian Interaktif}

Interakif berasal dari kata interaksi, yai-tu hal saling melakukan aksi, berhubungan, mempengaruhi, antar hubungan. Interaksi terjadi karena adanya hubungan sebab akibat, yaitu adanya aksi dan reaksi. Pengertian interaktif adalah hal yang terkait dengan komunikasi dua arah atau suatu hal bersifat saling melakukan aksi, saling aktif dan saling berhubungan serta mempunyai timbal balik antara satu dengan yang lainnya.

\section{Android}

Aplikasi Android ditulis dalam bahasa pemrograman Java, yaitu kode Java yang terkompilasi bersama-sama dengan data dan file resources yang dibutuhkan oleh aplikasi yang digabungkan oleh aapt tools menjadi paket Android, sebuah file yang ditandai dengan suffix .apk. File ini didistribusikan sebagai aplikasi dan diinstal pada perangkat, mobile. Android merupakan sistem operasi yang dikembangkan untuk perangkat mobile ber-basis Linux. Sistem operasi Android bersifat Open 
source (terbuka), sehingga banyak sekali programmer yang tertarik untuk membuat aplikasi maupun memodifikasi sistem operasi ini.

\section{Android SDK}

Android SDK adalah tools API (Application Programming Interface) yang di-perlukan untuk mulai mengembangkan aplikasi pada platform Android menggunakan bahasa pemrograman Java. Android SDK menyediakan tools dan API untuk pengembangan platform aplikasi Android dengan menggunakan bahasa pemograman java.

\section{Database}

Database adalah istilah yang menyata-kan kumpulan data yang tersimpan dalam ben-tuk yang mudah diakses oleh pemakai, sebuah database terdiri atas sejumlah tabel. Setiap tabel tersusun atas sejumlah baris dan kolom. Database merupakan pangkalan data (tempat data) yang disusun sedemikian rupa dengan tujuan database tersebut menjadi efisien dan efektif serta mengikuti aturan-aturan alat desain database, terlepas dari perangkat lunak pemograman yang digunakan.

\section{Data Flow Diagram (DFD)}

Data Flow Diagram (DFD) merupa-kan bentuk notasi yang dapat digunakan un-tuk membantu pemahaman mengenai tingkat kom-pleksitas suatu sistem secara logis. DFD dapat membantu menggambarkan sistem tanpa mempertimbangkan lingkungan fisik dari sistem tersebut. Dalam menggambarkan suatu sistem, DFD menggunakan simbol-simbol tertentu untuk mendefinisikan setiap bagian dari sistem. Simbol-simbol tersebut dianta-ranya : (1) External Entity (2) Data Flow (3) Process (4) Data Store.

\section{MySQL}

MySQL adalah salah satu nama data-base server. Database server adalah server yang menangani akses database. Dalam hal ini, akses ke sever selalu dalam bentuk pernyataan SQL. SQL (Structure Query Language) adalah suatu bahasa yang digu-nakan untuk mengakses database relasional. Bahasa ini mendukung perintah untuk membuat database, menciptakan tabel, menambah data, mengubah data, menghapus data, dan mengambil data. Tentu saja SQL juga menyediakan perintah untuk mengatur akses database sehingga keamanan data bisa terjamin. Artinya, bisa diatur agar pemakai tertentu hanya bisa mengakses data tertentu.
MySQL merupakan perangkat lunak yang dapat digunakan untuk pengolahan data-base berbasis client-server. MySQL menye-diakan bahasa pemograman SQL (Structure Query Language). MySQL menyediakan ban-yak fungsi, mulai dari manipulasi tanggal, ang-ka, string, dan sebagainya. MySQL sanggup melakukan pengolahan data dalam jumlah banyak.

MySQL mempunyai kekurangan dian-taranya adalah database ini tidak portable sebagaimana database Acces yang langsung bisa dipindah-pindahkan. Untuk memindahkan data pada MySQL harus dilakukan eksport terlebih dahulu baru kemudian di import ketempat atau komputer baru sehingga terkesan agak lama.

\section{Bahasa Pemrograman}

Bahasa pemrograman adalah perang-kat lunak atau software yang dapat digunakan dalam proses pembuatan program yang me-lalui beberapa tahapan-tahapan penyelesaian masalah.

\section{JavaScript}

JavaScript adalah bahasa script yang ditempelkan pada kode HTML dan diproses pada sisi klien. Dengan adanya bahasa ini, kemampuan dokumen HTML menjadi lebih luas. Sebagai contoh, dengan menggunakan JavaScript dimungkinkan untuk memvalidasi masukanmasukan pada formulir sebelum formulir dikirim ke server. Selain itu, dengan menggunakan JavaScript dimungkinkan untuk mengimplementasikan permainan interaktif seperti 'tiga jadi' (tic tac toe).

\section{Infeksi Virus Pada Anak}

Infeksi adalah proses invasif oleh microorganisme dan berproliferasi didalam tubuh yang menyebabkan sakit. Infeksi adalah beberapa penyakit yang disebabkan oleh pertumbuhan organisme patogenik dalam tubuh Anak merupakan individu yang berada dalam satu rentang perubahan perkembangan yang dimulai dari bayi hingga remaja. Pada dasarnya penyakit pada anak dapat disebabkan oleh banyak faktor. Pada umumnya penye-banya adalah virus. Virus adalah organisme yang amat halus. Karena amat halusnya itu tidak dapat dilihat dengan mikroskop biasa. Untuk itu diperlukan suatu mikroskop electron yakni mikroskop yang mampu membesarkan sampai $1.000 .000 \mathrm{X}$. Jenis-jenis virus yang da-pat menimbulkan penyakit-penyakit yakni ca-car, gondongan, influenza, selema atau Com-mon Cold dan lain sebagainya. 
Penyakit infeksi virus ini sangat rentan terjadi pada anak-anak, karena sistem imunitas pada tubuh anak belum terbangun secara sem-purna. Lingkungan juga menjadi faktor yang mempengaruhi rentannya suatu penyakit infeksi virus menyerang anak. Anak-anak yang tumbuh di lingkungan padat dengan udara dan sanitasi buruk lebih rentan terserang penyakit dan akan menurunkan imunitas tubuh pada anak. Penyakit infeksi virus akan mudah menjangkit anak-anak dengan imunitas yang lemah.

\section{METODE DAN PERANCANGAN SISTEM}

\section{Kerangka Berpikir}

Dalam membuat perancangan sistem interakif dalam diagnosa penyakit infeksi vi-rus pada anak, maka perlu dilakukan suatu analisa dengan tahapan sebagai berikut:

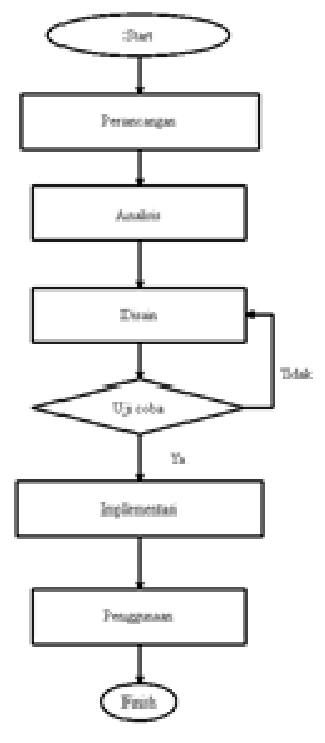

Gambar 1 Kerangka Berpikir

\section{Metode Penelitian}

Dalam melakukan penelitian metode yang digunakan untuk perancangan sistem in-teraktif diagnosa penyakit infeksi virus pada anak ini adalah dengan menerapkan siklus hi-dup pengembangan sistem (Systems Develop-ment Life Cycle) SDLC atau sering kali dise-but sebagai pendekatan air terjun (waterfall approach) yang meliputi tahap perencanaan, tahap analisis, tahap desain, tahap implementasi, dan tahap penggunaan.

\section{Desain Sistem}

Pada tahap desain sistem hal yang ha-rus dilakukan untuk membuat sistem yang akan dibangun adalah dengan menggunakan rancangan DFD (Data Flow Diagram) dan Desain tampilan antar muka (Interface).

\section{Diagram Aliran Data}

Diagram Aliran Data atau Data Flow Diagram (DFD) adalah sebuah teknis grafis yang menggambarkan aliran informasi dan transformasi yang diaplikasikan pada saat data bergerak dari input menjadi output.

DFD dapat digunakan sebagai media dalam merepresentasikan sebuah sistem perangkat lunak pada level abstraksi. DFD dapat dibagi menjadi beberapa level yang lebih detail untuk merepresentasikan aliran data atau fungsi yang lebih detail (DFD berting-kat/levelled).

\section{Diagram Konteks}

Diagram konteks merupakan gambaran secara umum mengenai sebuah sistem yang dirancang secara global, yaitu suatu diagram yang mempresentasikan atau mengambarkan hubungan antara sistem dengan lingkungan luar sistem yang mempengaruhi operasi sistem. Sistem ditunjukan dalam satu lingkungan yang mengambarkan keseluruhan proses dalam sistem dan hubungannya dengan entitas. Terdapat sebuah entitas yang terhubung langsung dengan sistem yaitu pengguna (user). Adapun diagram konteks pada sistem pakar ini dapat dilihat pada gambar dibawah ini.

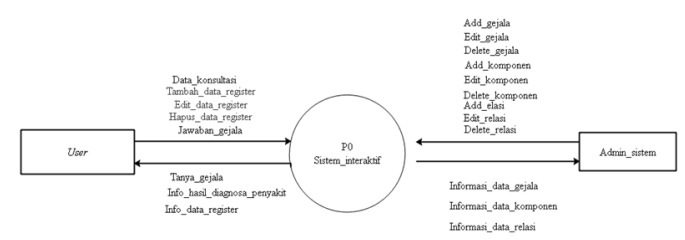

Gambar 2 Diagram Konteks

\section{DFD Level 0}

Data Flow Diagram (DFD) adalah diagram alir yang dipresentasikan dalam bentuk lambang-lambang tertentu yang menunjukan aliran data, proses, tempat penyimpanan data, dan entitas eksternal. Data Flow Diagram dibuat untuk mengetahui suatu proses dari diagram konteks yang di buat dalam penjabaran yang lebih umum dan dibagi dalam beberapa proses. 


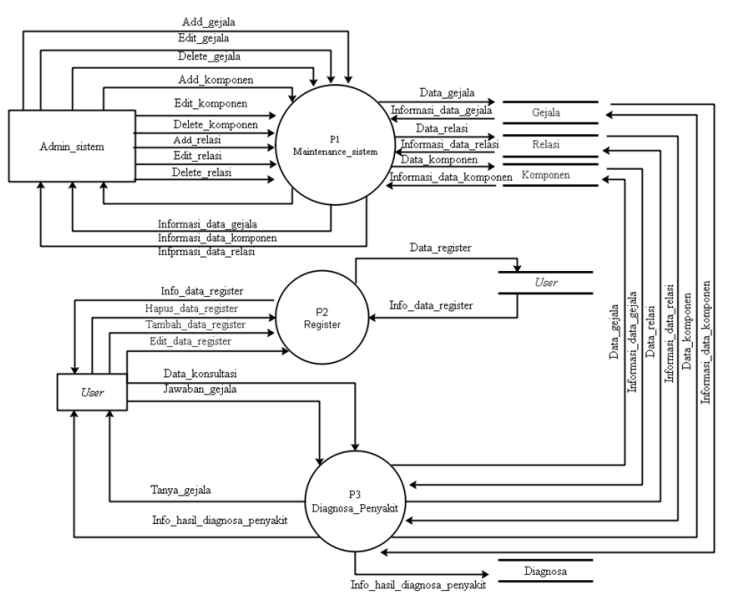

Gambar 3 DFD Level 0

\section{ERD (Entity Relationship Diagram)}

Diagram relasi entitas, seperti ditunjukkan oleh namanya, berhubungan dengan data di dalam entitas dan hubungan antar entitas. Ketika pengguna dan spesialis informasi mulai untuk berkomunikasi tentang kebutuhan data untuk suatu sistem informasi, mereka akan berbicara mengenai pengumpulan field data yang saling berhubungan, field yang saling berhubungan ini disebut entitas.

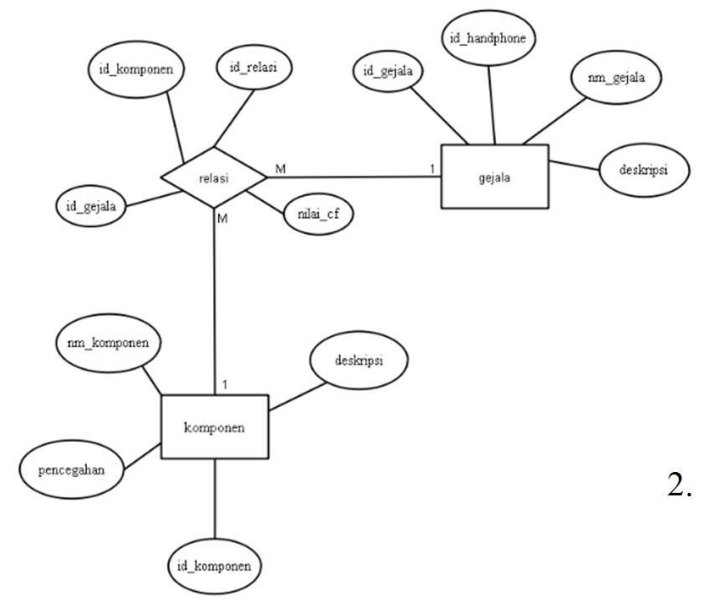

\section{Gambar 4 ERD (Entity Relationship Diagram)}

Gambar 4 menunjukan relasi antara tabel gejala, relasi, dan komponen, tabel relasi menjadi penghubung antara tabel gejala dan komponen dimana atribut tabel gejala dan tabel komponen yang merupakan primary key menjadi foreign key didalam tabel relasi

\section{IMPLEMENTASI SISTEM}

\section{Implementasi Sistem}

Implementasi sistem adalah tahap penerapan dan pengujian untuk sistem berdasarkan hasil analisa dan perancangan yang telah dilakukan pada bab III. Pada bab IV merupakan bagian untuk melakukan pengiplementasian dari hasil rancangan menjadi sebuah aplikasi sistem interaktif berbasis android dalam mendiagnosis penyakit infeksi virus pada anak di Poliklinik Anak.

\section{Antar Muka Sistem (Interface)}

Tampilan antar muka merupakan gambaran mengenai tampilan sistem yang telah dibuat.

1. Menu Utama

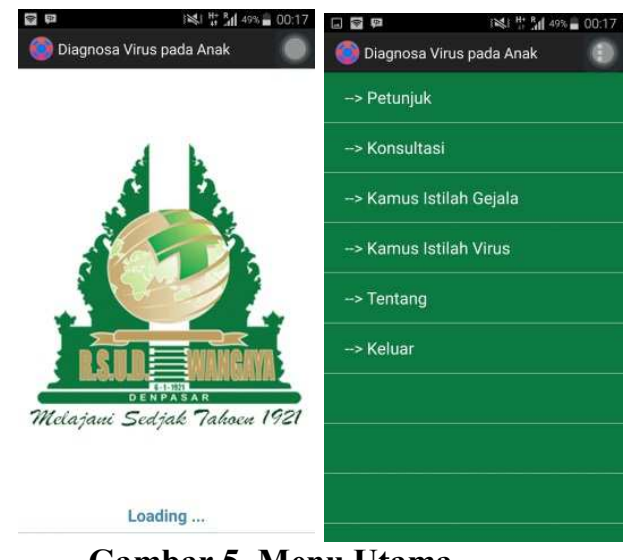

Gambar 5 Menu Utama

Menu utama dimana merupakan menu awal yang muncul saat aplikasi di buka. Terdapat beberapa pilihan menu utama dalam aplikasi interaktif ini seperti menu petunjuk, menu konsultasi,kamus istilah gejala, kamus istilah virus, dan menu tentang.

2. Menu Konsultasi

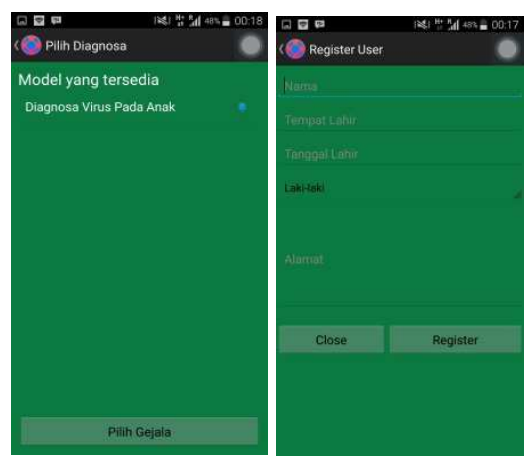

Gambar 6 Menu Konsultasi

Ketika user memilih menu konsultasi maka user harus melakukan registrasi terlebih da- 
hulu, setelah itu didalam menu konsultasi akan muncul kotak dialog yang mengha-ruskan user untuk memilih kategori konsultasi yang diinginkan yaitu konsultasi diagnosa penyakit virus apada anak, dan sistem interaktif akan memunculkan menu selanjutnya.

3. Menu Pertanyaan
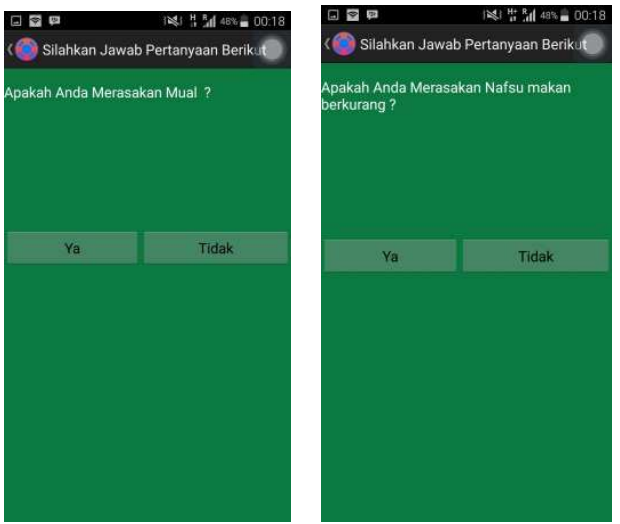

Gambar 7 Menu Pertanyaan

Menu ini akan dimunculkan pertanyaanpertanyaan yang berhubungan dengan penyakit infeksi virus pada anak. Pertanyaan yang muncul dalam aplikasi ini berdasarkan pada gejala yang dialami oleh pasien anak tersebut, yang kemudian akan dianalisis oleh sistem interaktif berdasarkan kemungkinan diagno-sis awal yang paling mendekati berdasarkan gejala-gejala yang dialami.

\section{Halaman Hasil Analisis Penyakit}

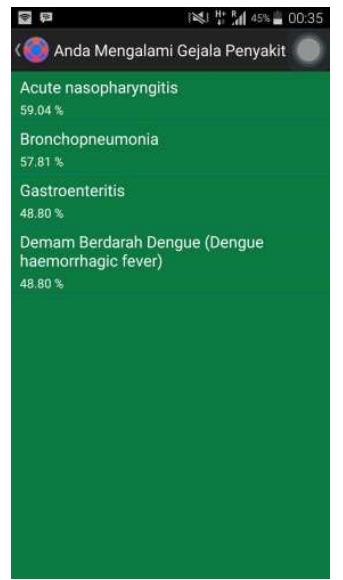

\section{Gambar 8 Halaman Hasil Analisis Penyakit}

Dari pertanyana-pertanyaan yang telah dijawab, sistem akan memberikan hasil analisis berdasarkan gejala yang telah di ja- wab. Sistem interaktif ini akan memberikan analisis diagnosis awal dari hasil jawaban user. Analisis akan berupa persentase kemungkinan penyakit yang dialami oleh user.

\section{Kamus Istilah Gejala dan Virus}

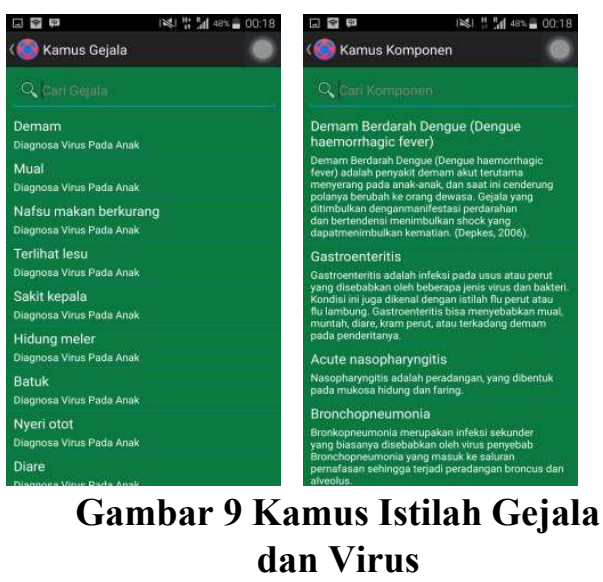

Dalam menu kamus istilah gejala akan muncul tentang berbagai gejala penyakit yang ada dalam sistem ini beserta penjelasan singkat dan kategori gejala penyakit. Menu ini memudahkan pengguna dalam memahami istilah gejala yang ada didalam sistem interaktif ini.

Terdapat beberapa jenis penyakit infeksi virus pada anak pada menu ini. Tiap-tiap penyakit diberi informasi mengenai penyakit tersebut dan juga beberapa gejala-gejala dari masing-masing penyakit.

6. Antar muka sistem admin

\section{a. Login Admin}

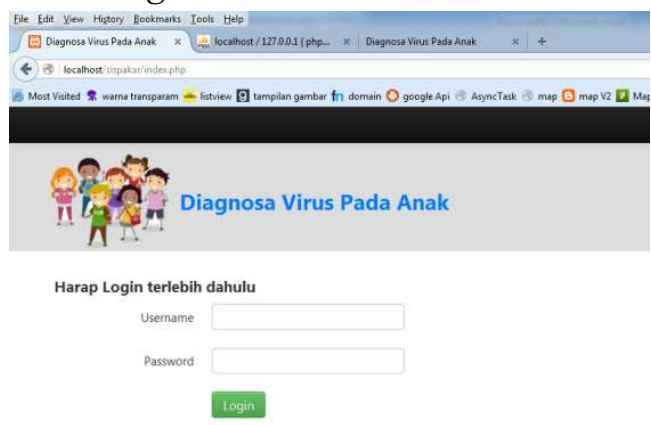

Gambar 10 Login Admin

Untuk dapat melakukan akses kedalam sistem interakif ini adalah dengan memasukan alamat http://localhost/sispakar/index.php pada web browser, maka akan terhubung pada localhost untuk mengakses data server apli-kasi dan akan langsung muncul halaman login admin. Admin 
dapat langsung melakukan login menggunakan username dan password khusus admin dan masuk ke halaman utama.

b. Halaman Utama

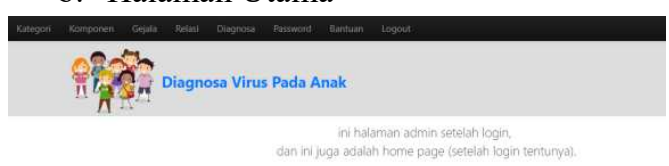

Gambar 11 Halaman Utama

Setelah melakukan login admin, maka akan muncul halaman utama yang memperlihat beberapa menu utama.

\section{c. Halaman Kategori}

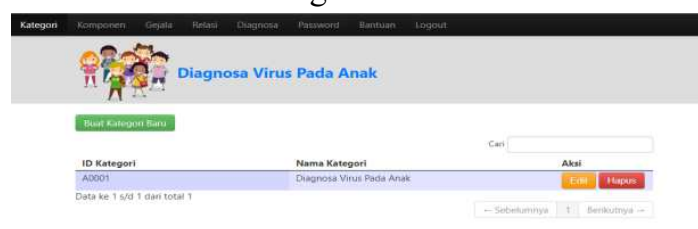

\section{Gambar 11 Halaman Kategori}

Untuk melakukan penambahan kategori diagnosis dapat dilakukan dengan cara mengklik kategori, maka muncul halaman kategori. Dalam halaman ini terdapat beberapa fitur yang dapat diakses yaitu: membuat kategori baru, meng-edit dan menghapus kategori yang sudah ada.

\section{d. Halaman Utama Menu Komponen}

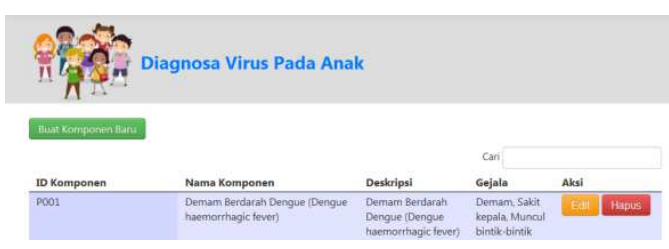

Gambar 12 Halaman Utama Menu Komponen

Admin dapat melakukan penambahan komponen dalam menu komponen selain, menambah komponen terdapat beberapa fitur lainnya antara lain : tambah komponen, edit komponen, dan hapus komponen.

\section{SIMPULAN}

Sistem interaktif ini merupakan sistem yang dirancang dan dibangun dengan teknologi berbasis Android. Sistem ini dapat membantu proses pencatatan dalam penegakan diagnosis penyakit infeksi virus pada anak di Poliklinik Anak

Penelitian ini berhasil merancang sistem interaktif berbasis android untuk membantu proses pencatatan dalam penegakan diagnosis penyakit infeksi virus pada anak di Poliklinik Anak Rumah Sakit Umum Daerah (RSUD) Wangaya Kota Denpasar.

\section{DAFTAR PUSTAKA}

[1] Aden, R. 2010. Seputar Penyakit dan Gangguan Lain Pada Anak.

Yogyakarta: Hanggar Kreator.

[2] Alimul Hidayat,A.Aziz. 2005.

Pengantar ilmu keperawatan anak 1., Jakarta: Salemba Medika.

[3] Bambang Warsita. (2008). Teknologi

Pembelajaran, Landasan dan

Aplikasinya. Jakarta: Rineka Cipta.

[4] Jogiyanto Hartono M, 2005. Analisis dan Desain Sistem Informasi : Pendekatan Terstruktur Teori dan Praktek Aplikasi Bisnis. Yogyakarta: Andi

[5] Kadir, Abdul., 2003. Pengenalan Sistem Informasi. Yogyakarta : ANDI.

[6] Kadir, Abdul. 2010. Dasar Pemograman Web Dinamis Menggunakan Php. Yoyakarta: Andi Offset

[7] Kusrini,. 2007. Konsep dan Aplikasi Sistem Pendukung Keputusan.

Yogyakarta: ANDI OFFSET.

[8] McLeod, Raymond ,Jr. 2001. Sistem Informasi. Edisi 7 Jilid 2. Prenhallindo. Jakarta

[9] Mulyadi, ST., 2010. Membuat aplikasi untuk android. Yogyakarta: Multimedia Center Publishing.

[10] Turban, Efraim Aranson, Jae E, and Liang, Tim Peng. 2005, Decision Support System and System Intelegence. 7th Edition, jilid 1. 